\title{
The Development of the Valid Test Instruments to Measure Metacognition Problem Solvers
}

\author{
Evita Kusumawati ${ }^{1, *}$ Budiyono $^{2}$ Diari Indriati ${ }^{3}$ \\ ${ }^{1}$ Postgraduate of Mathematics Education, Faculty of Teacher Training and Education, Universitas Sebelas \\ Maret Surakarta, Indonesia \\ ${ }^{2}$ Faculty of Teacher Training and Education, Universitas Sebelas Maret Surakarta, Indonesia \\ ${ }^{3}$ Faculty of Mathematics and Natural Sciences, Universitas Sebelas Maret Surakarta, Indonesia \\ *Corresponding author. Email: evitakusumawati@student.uns.ac.id
}

\begin{abstract}
This study aims to determine the validity of developing tests to measure students' metacognitive abilities in problem-solving. This research is motivated by the test questions that less varied teachers usually give. With metacognition skills in problem-solving, students can recognize a problem, know the problem, and know how to solve the problem. This type of research and development adopts the RRD development procedure. This research was carried out in three stages: information gathering, product development, and preliminary testing \& revision. The research instrument used was a test instrument and a validation sheet. Data analysis was carried out by describing the responses, statements, and suggestions of the three validators. The results of expert validation show that the average instrument feasibility value of the three validators is included in the very feasible criteria. The test results of validity, reliability, level of difficulty, and discriminatory power also show that the questions are reasonable and feasible. This shows that the test instrument developed is ready to be used. This research is still limited to two variable linear equation systems problem material. Further researchers can develop test instruments to improve metacognition skills in problem-solving with various materials.
\end{abstract}

Keywords: Metacognition, Problemsolving, Test instruments.

\section{INTRODUCTION}

Learning mathematics is a high mental activity because it requires a thought process to compile the information obtained, store it, and re-disclose the information. This is known as a cognitive activity. Cognitive activity is one component of the metacognitive process, namely a person's awareness related to cognitive abilities, about what is known and what is not known based on the knowledge already possessed [1]. Metacognition is a person's awareness of his thinking process [2]. In addition, metacognition is a person's knowledge of cognitive processes related to the properties of information or data [3]. Metacognition is also a form of cognition, a higherorder thinking process involving active control in cognitive activities [4]. Metacognition is also defined as a person's thinking process concerning how he builds a strategy used to solve a problem. This strategy is a metacognitive strategy from within students and one of the factors that can influence the success or failure of students in solving a mathematical problem [5]. Metacognition has an essential role in problemsolving [6], especially in solving mathematical problems [7]. Metacognition can be used to solve a contextual problem in mathematics [8]. In mathematics learning, metacognition can be used when students are asked to express mathematical ideas or discuss in groups in solving a mathematical problem [9]. Metacognition in problem-solving can help someone recognize a problem, know the problem, and know how to solve the problem [10]. Metacognition of problem solvers is the ability to realize, know, and control the thinking processes that occur in themselves to find appropriate strategies in solving problems [11]. Thus, metacognition has an essential role in the success of learning, especially in the problem-solving process. 
Therefore, it is essential to develop a test instrument to measure students' metacognitive abilities that have problem-solving in it.

Various relevant studies are related, the development of instruments with a metacognitive approach [12]; the process of developing students' metacognition assessment instruments in solving math story problems [13]; the validity of the metacognitive ability instrument [14]; and the development of worksheets in problem-solving [15]. Based on several references that have been reviewed, there is a gap that needs to be investigated, namely how the metacognition of developing a valid test instrument to measure the metacognition of problem solvers is found. The novelty in this research is developing a mathematical instrument test on the material of a twovariable linear equation system that is used to measure the metacognitive ability of problem solvers based on aspects of awareness, evaluation, and regulation.

Metacognition has three components, awareness, regulation, and evaluation [16]. Metacognition awareness is a person's awareness of solving the problems encountered and includes knowledge of strategies to solve problems. Metacognition regulation is one's knowledge of oneself how and why to use these problem-solving strategies. Metacognition evaluation is an assessment of the thinking process [17]. The components and indicators of metacognition are presented in Table 1.

Table 1. Components and indicators of metacognition process

\begin{tabular}{|c|c|}
\hline Components & Indicators \\
\hline Awareness & $\begin{array}{l}\text { 1. Understand the problem } \\
\text { 2. Knowing the initial knowledge that can be used to solve problems } \\
\text { 3. Determine the method that will be used to solve the problem }\end{array}$ \\
\hline Regulation & $\begin{array}{l}\text { 1. Knowing whether the steps taken to solve the problem are suitable with the plan } \\
\text { 2. Identify new problems that arise so that they can be resolved immediately } \\
\text { 3. Assess the method used whether it is appropriate to solve the problem } \\
\text { 4. Knowing that the answers that are done are suitable with the problems given }\end{array}$ \\
\hline Evaluation & $\begin{array}{l}\text { 1. Knowing that he is proficient or not in solving problems } \\
\text { 2. Determine the actions that must be taken to master the initial knowledge and be } \\
\text { proficient in solving problems } \\
\text { 3. Find out if there are other ways to solve the problem }\end{array}$ \\
\hline
\end{tabular}

Developing test instruments to measure students' metacognitive abilities is essential because metacognition plays an essential role in learning success, especially in the problem-solving process. Thus, the expected result is a valid instrument to measure students' metacognitive ability to be a reference in the learning process so that students' metacognitive abilities in problem-solving can be optimized. This study aims to develop a valid test instrument and conduct it in a small class, including validity, reliability, discriminatory power, and difficulty level.

\section{RESEARCH METHODOLOGY}

\subsection{Research Design}

The method used in this research is the Research and Development method (R \& D). According to Borg $\&$ Gall, research development in the field of education is a process used to develop and validate educational products. [18].

\subsection{Research Instruments}

The development product in this research is a valid test instrument designed to measure students' metacognitive abilities in problem-solving. The development model used is a modification of the Borg \& Gall, Dick \& Carey development model, and the Kemp model, which is called the Real Research and Development (RRD) development model, which includes five stages, namely: (1) information gathering, (2) instrument development, (3) preliminary and revision tests, (4) operational tests, revisions, and data collection, and (5) dissemination and implementation [19]. At the information gathering stage, planning is carried out, which includes defining abilities, formulating goals, and identifying fundamental problems related to student metacognition in problem-solving either directly in the 
field or through literature studies. Product development is done by compiling test instruments. Then, at the preliminary and revision stage, the instrument consisting of a test instrument and a validation sheet was sent to the validator. Then, improvements were made according to suggestions and comments from the validator. In the revised operational test and data collection, the developed test instrument trials were carried out. Then, at the dissemination and implementation stage, the final instrument that has been tested is disseminated.

\subsection{Data Collection Technique}

The data collection technique used in this study is collecting validity sheet data obtained from the validator. The validator will provide an assessment by giving a checkmark from the existing assessment aspects of the test questions with choices of very good (5), good (4), quite good (3), less good (2), and not good (1). Then, add up the total score of each validator, look for the average validity, and categorize the eligibility criteria for the questions presented in Table 2 [20].

Table 2. Eligibility criteria for test questions

\section{Score Interval}

\begin{tabular}{|c|c|}
\hline $4 \leq \mathrm{Va} \leq 5$ & Very Decent \\
\hline $3 \leq \mathrm{Va}<4$ & Worthy \\
\hline $2 \leq \mathrm{Va}<3$ & Less worthy \\
\hline $1 \leq \mathrm{Va}<2$ & Improper \\
\hline
\end{tabular}

\section{$\mathrm{V}_{\mathrm{a}}$ : Validity Average}

After the expert validation test was carried out, the test instrument was conducted on students to determine the questions' validity, reliability, discriminatory power, and level of difficulty.

\subsubsection{Item Validity} $[21]$

The formula used to determine item validity is:

$$
r_{x y}=\frac{N \sum X Y-\left(\sum X\right)\left(\sum Y\right)}{\sqrt{\left\{N \sum X^{2}-\left(\sum X^{2}\right)\right\}\left\{N \sum Y^{2}-\left(\sum Y^{2}\right)\right\}}}
$$

Descriptions:

$\mathrm{r}_{\mathrm{xy}}=$ Correlation Coefficient of each item

$\mathrm{N}=$ The number of test subjects

$\mathrm{X}=$ Score item questions

$\mathrm{Y}=$ Total score
The results of the $r_{x y}$ calculation are then compared with the rtable. Suppose $r_{x y}>r_{\text {table }}$ with a significant level of $5 \%$. then the question is said to be valid. In other words, if $r_{x y}<r_{\text {table }}$, then the question is said to be invalid.

\subsubsection{Reliability}

Reliability for the description test questions used the Alpha formula: [21]

$$
r_{11}=\left(\frac{n}{n-1}\right)\left(1-\frac{\sum \sigma_{i}^{2}}{\sigma_{i}^{2}}\right)
$$

Descriptions:

$\mathrm{r}_{11}=$ Question reliability

$\mathrm{n}=$ Number of questions

$\sum \sigma_{i}^{2}=$ Total score variance for each item $\sigma_{i}{ }^{2}=$ Total variance

The calculation results are compared with $\mathrm{r}_{\text {table }}$ with a significant level of $5 \%$. If $r_{11}>r_{\text {table, the test }}$ instrument is said to be reliable.

\subsubsection{Distinguishing Power}

The discriminatory power formula for the test instrument is in the form of description questions:

$$
D P=\frac{\bar{X}_{A}-\bar{X}_{B}}{\text { Skor Maks }}
$$

Descriptions:

$\mathrm{DP}=$ Distinguishing power

$\overline{X_{\mathrm{A}}}=$ Upper group average

$\overline{X_{\mathrm{A}}}=$ Lower group average

According to the terms of the discriminatory index, discriminatory power is classified into four categories (Table 3).

Table 3. Distinguishing power category

\begin{tabular}{|c|c|}
\hline Distinguishing Power & Category \\
\hline$D \geq 0.40$ & Very good \\
\hline $0.30-0.39$ & Good \\
\hline $0.20-0.29$ & Enough \\
\hline$D \leq 0.19$ & Not good \\
\hline
\end{tabular}

\subsubsection{Difficulty Level}

The formula used to analyze the level of difficulty:

$$
T K=\frac{\bar{X}}{\text { Skor maks }}
$$


Descriptions:

TK = Difficulty Level

$\bar{X}=$ The average value of each item

Conditions for the difficulty index category [21] (Table 4).

Table 4. Category difficulty level

\begin{tabular}{|c|c|}
\hline Difficulty Level & Category \\
\hline $0.00<\mathrm{TK} \leq 0.30$ & Difficult \\
\hline $0.31<\mathrm{TK} \leq 0.70$ & Moderate \\
\hline $0.71<\mathrm{TK} \leq 1.00$ & Easy \\
\hline
\end{tabular}

\subsection{Data Analysis}

The Eligibility test for each item was obtained through validation by the validator in the form of responses and assessments as material for improving the developed instrument [22]. The developed instrument is ready to be used if valid, contains good points, and is reliable. Usually, the item is said to be good if the discriminatory power and difficulty level is good.

\section{RESULT AND DISCUSSION}

\subsection{Information Gathering}

This stage is the initial stage in developing a problem solver's metacognitive ability test instruments. At this stage, an analysis of the problems and needs of students is carried out. A problem analysis was used to determine the fundamental problems in developing test instruments metacognition ability problem solvers. In this step, the researcher observes the problems that arise in the test on the two variable linear equation systems problem material. Analysis of student needs, namely, students need innovations related to the two variable linear equation systems problem material test instrument. This innovation as a researcher's offer is to develop a student metacognitive ability test instrument in problem-solving. The test instrument was developed in the form of description questions and instructions for working on the questions.

\subsection{Instrument Development}

This stage is the stage of making an instrument to measure the metacognitive ability of problem solvers. The test instrument was developed in the form of a description of the two variable linear equation systems problem material. The steps taken to develop the test instrument are establishing Fundamental
Competencies, which will be the basis for developing the instrument, formulating indicators, formulating questions based on indicators, and compiling answer keys. The examples of test instrument questions that have been developed can be seen in Figure 1 .

1. Solve the following two-variable system of linear equations:

$3 x+2 y=8$

$x+3 y=5$

2. Putri buys four erasers and two rulers. Putri must pay as much as Rp. 15,000. Putri buys three erasers and four rulers. Putri must pay as much as Rp. 14,000. Determine the price of one eraser and the price of one ruler!

Figure 1 Unrevised test instrument

Aspects assessed in the development of this test instrument are construction, material, and language. In the construction aspects assessed, namely: the words used, instructions for working on the questions, scoring guidelines, and the problems presented. In the aspects of the material assessed, namely: the suitability of the questions with fundamental competencies and indicators, question limits, material according to competence, and content according to a school level or grade level. The aspects of language assessed are: The language used is communicative, the clarity of the words used, the use of standard Indonesian, and not taboo.

\subsection{Preliminary Test and Revision}

The preliminary and revision test phase begins by sending the instrument developed to the validator by paying attention to construction, material, language, instruments, and validation sheets for later improvement. According to Gelerstein et al., validation was carried out to check the suitability of the relationship between the questions and the test objectives [23]. In addition, the purpose of validation is to determine the validity of the contents of the instrument in terms of construction, material, language, and the suitability of the questions in the test with indicators [24]. Three validators carried out the validation in this study. Validator 1 is a lecturer from Muhammadiyah University of Surakarta, validator 2 is a mathematics teacher at SMP Negeri 1 Surakarta, and validator 3 is a mathematics teacher at SMP Muhammadiyah 8 Kebakkramat. 
Here is a briefing (Figure 2) and test instruments (Figure 3), which have been revised.

- Write down what is known and asked from the question!

- Write a mathematical model of the problem on the problem!

- Choose and write down the method you will use to solve the problem (Graphic Method, Substitution Method, Elimination Method, and Mixed Methods)!

- Write down the reasons why you chose this method over the other three!

- Write the complete steps of the method you have chosen!

- Solve the problem in the question using one of the four solution methods that you have learned!

- Write down the conclusion of your work!

- Are you sure that what you are doing is correct?

- Have you reviewed your work? If so, write down how to recheck your work?

- Are there any other events to check back on? If yes, please explain. If not, why?

Figure $2 \mathrm{~A}$ briefing from validators

1. Solve the following two-variable system of linear equations:

$3 x+2 y=8$

$x+3 y=5$

2. If Putri buys four erasers and two rulers, the money to be paid is Rp. $15,000.00$. If she buys three erasers and four rulers, she must pay Rp. 14,000.00. How much money does Putri pay if she buys an eraser and a ruler?

Figure 3 Revised test instrument

Here (Figure 4, Figure 5, and Figure 6) is an example of a validation sheet that the validator has filled in.

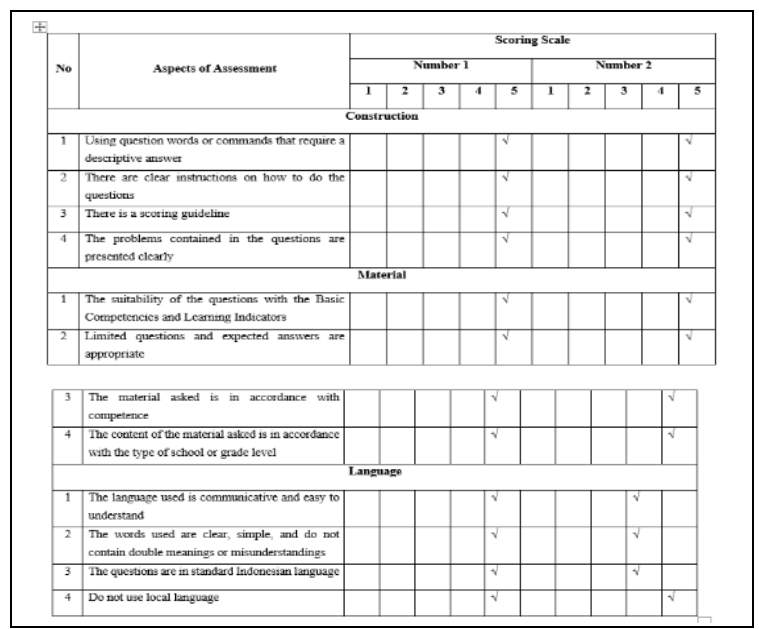

Figure 4 Validation sheet from validator 1

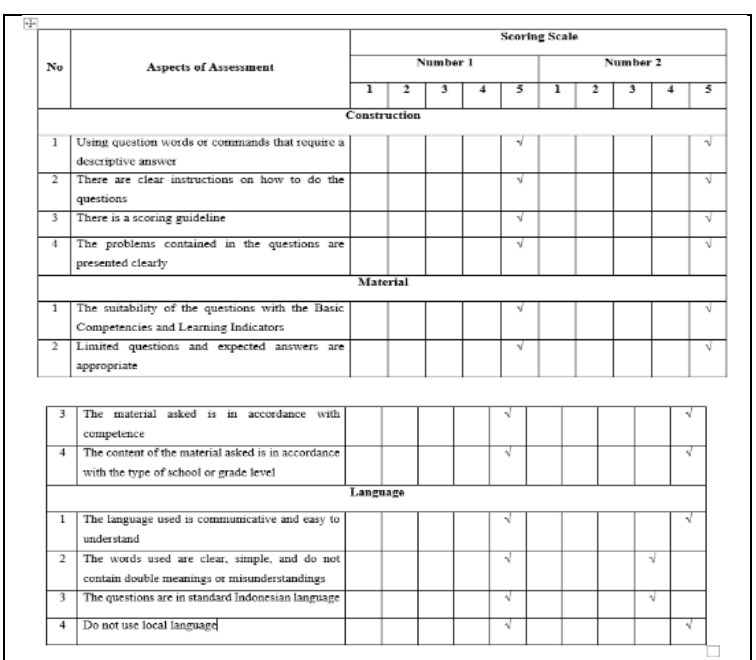

Figure 5 Validation sheet from validator 2

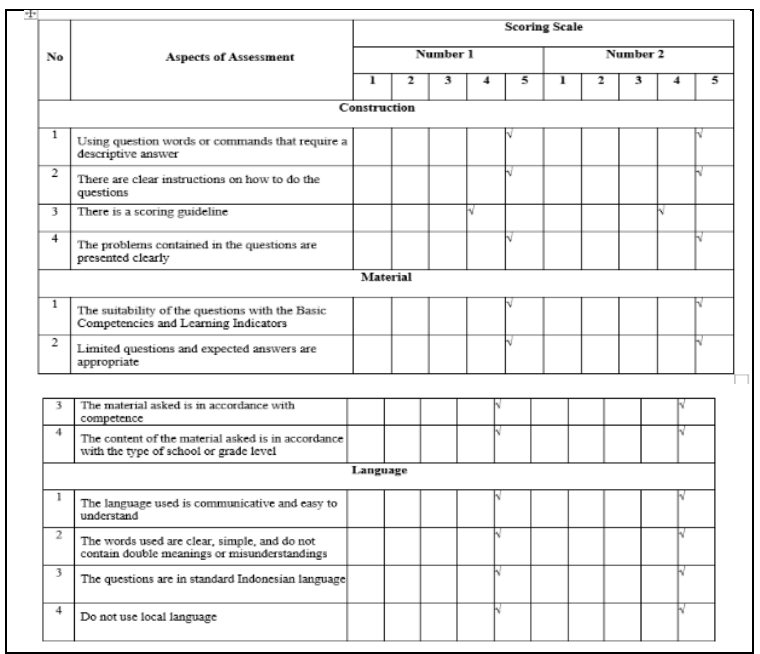

Figure 6 Validation sheet from validator 3

The first step after expert validation is to calculate the average of each aspect on each question from each validator. Then, calculate the total average of each validator. The last step is to determine whether or not the question is feasible or not, seen from the total average of the three validators. The validation results of the three validators can be seen in Table 5 .

Table 5. Validity test results from experts

\begin{tabular}{|c|c|c|c|}
\multirow{2}{*}{ Validator } & \multicolumn{3}{|c|}{ Average Value } \\
\cline { 2 - 4 } & Construction & Material & Language \\
\hline V1 & 5 & 5 & 4.125 \\
\hline V2 & 5 & 5 & 4.75 \\
\hline V3 & 4.75 & 5 & 5 \\
\hline $\begin{array}{c}\text { Average } \\
\text { value }\end{array}$ & 4.708 & 4.917 & 4.917 \\
\hline Criteria & $\begin{array}{c}\text { Very } \\
\text { Decent }\end{array}$ & $\begin{array}{c}\text { Very } \\
\text { Decent }\end{array}$ & $\begin{array}{c}\text { Very } \\
\text { Decent }\end{array}$ \\
\hline
\end{tabular}




\subsection{Operational Test and Revision}

At this stage, the test instrument was tested on students after the expert validity test was carried out. After the test instrument has been tested, the next step is to calculate the item validity, reliability, level of difficulty, and discriminating power. The results obtained from the item validity can be seen in Table 6 .

Table 6. Item validity test results

\begin{tabular}{|c|c|c|c|}
\hline $\begin{array}{c}\text { Question } \\
\text { Number }\end{array}$ & $\begin{array}{c}\text { Value } r \\
\text { Values }\end{array}$ & $\begin{array}{c}\text { Table } r \\
\text { Values }\end{array}$ & $\begin{array}{c}\text { Table } r \\
\text { Values }\end{array}$ \\
\hline 1 & 0.980 & 0.444 & Valid \\
\hline 2 & 0.975 & 0.444 & Valid \\
\hline
\end{tabular}

In the reliability test, the value obtained is 0.952 , so that the questions are said to be reliable. In the difficulty level test, the results obtained from the calculations can be seen in Table 7 .

Table 7. Difficulty level test results

\begin{tabular}{|c|c|c|}
\hline $\begin{array}{c}\text { Question } \\
\text { Number }\end{array}$ & Calculation Value & Criteria \\
\hline 1 & 0.79 & Easy \\
\hline 2 & 0.413 & Moderate \\
\hline
\end{tabular}

Distinguishing power is divided into four categories, namely very good, good, enough, not good. In the discriminatory power test, the results obtained are 0.28 for item number 1 , which is categorized as enough, and 0.105 , which is categorized as not good for item number 2. sufficient discriminating power. The test instrument developed was good concerning test results of validity, reliability, level of difficulty, and distinguishing power.

\subsection{Dissemination and Implementation}

At this stage, an article is prepared to disseminate information related to developing a valid test instrument to measure the metacognitive ability of problem solvers.

\section{DISCUSSION}

The test instrument was developed in the form of description questions and instructions for working on the questions. The test instrument developed was guided by the test grid [25]. The instrument is declared very feasible in the construction aspect, which is categorized with the eligibility criteria. Likewise, the instrument is declared very feasible with the eligibility criteria by the material and language aspects. According to the three aspects assessed, the test instrument made is feasible to use [26]. The development of an instrument to measure the metacognitive ability of problem solvers can be done by providing description questions [27]. One of the description questions that can be applied is a question related to problem-solving [28]. Based on the results of the tests carried out, the test instrument developed can be used to measure the metacognitive ability of problem solvers on the subject of two variable linear equation systems problem.

The validator validates the instrument that has been compiled. According to the eligibility criteria, the instrument developed is feasible if it is categorized as feasible or very feasible [24]. The instruments are categorized based on the eligibility criteria for questions after several revisions have been made based on comments and suggestions for improvement of the validator [19]. The results of the validation calculations concluded that the two items were declared valid. The instrument question was then analyzed for its reliability test and obtained a result of 0.952 and was declared reliable. The difficulty level of the items is included in the easy and moderate categories. The second item has enough discriminating power so that the questions are good to use. This is in line with the research of Syarifatul et al., which stated that the test items were declared valid and reliable, good and feasible to use [29].

\section{CONCLUSION}

Based on the average results of the validation test, it was found that the average validity of the instrument from the construction aspect was 4.708, which was categorized with the eligibility criteria, then the instrument was declared very feasible. Later, the material aspect is 4.917 , which was categorized with the eligibility criteria, then the instrument is declared very feasibly. Then, the language aspect is 4.917, which was categorized with the eligibility criteria, then the instrument is declared very feasibly. The test results also stated that the questions were valid, reliable, had easy and moderate levels of difficulty, and had good distinguishing power. Based on the results of the validation of the three validators in terms of construction, material, and language, it can be concluded that the two variable linear equation systems problem material test instrument that was developed was declared feasible to be used to measure students' metacognitive abilities in problem-solving with minor revisions. Based on the test results of validity, reliability, level of difficulty, and discriminating power, it can be concluded that the 
questions are reasonable and feasible to use. The teacher as a learning manager is an essential element in improving the metacognitive ability of problem solvers. Teachers must also be more creative in managing learning by developing test instruments to respond to the teaching delivered positively. This research is still limited to two variable linear equation systems problem material. Further researchers can develop test instruments to measure the metacognitive ability of problem solvers with various materials.

\section{REFERENCES}

[1] Z. Chairani, Metakognisi Siswa dalam Pemecahan Masalah Matematika, Ke-1. Yogyakarta: Deepublish, 2016.

[2] M. F. Annur, I. Sujadi, dan S. Subanti, "Aktivitas Metakognisi Siswa Kelas X SMAN 1 Tembilahan dalam Pemecahan Masalahan Matematika ditinjau dari Daya Kognitif," vol. 4, no. 7, hal. 720-730, 2016.

[3] J. H. Flavell, "Theories of Learning in Educational Psychology: Metacognition Theory," Nat. Intell., no. 1979, hal. 231-235, 1979.

[4] B. Y. L Wong, "Metacognition (reading 3) Metacognition and Learning Disabilities," hal. 137-180, 1985.

[5] Melanie G. Gurat, C. T. Medula, dan JR, "Metacognitive Strategy Knowledge Use through Mathematical Problem Solving amongst Pre-service Teachers," Am. J. Educ. Res., vol. 4, no. 2, hal. 170-189, 2016, doi: 10.12691/education-4-2-5.

[6] Rezki Hidayanti, Nurdin, dan Fajar, "Analisis Kesulitan Siswa Dalam Memecahkan Masalah Sistem Persamaan Linear Dua Variabel(Spldv) Ditinjau Dari Kesadaran Metakognisi," Univ. Negeri Makasar, vol. 11, no. 1, hal. 1-14, 2019, [Daring].

[7] T. Novita, W. Widada, dan S. Haji, "Metakognisi Siswa dalam Pemecahan Masalah Matematika Siswa SMA dalam Pembelajaran Matematika Berorientasi Etnomatematika Rejang Lebong," J. Pendidik. Mat. Raflesia, vol. 3, no. 1, hal. 41-54, 2018, [Daring]. Tersedia pada: https://ejournal.unib.ac.id/index.php/jpmr.

[8] W. Marliana dan I. N. Aini, "Analisis Kemampuan Metakognisi Siswa SMP pada Materi Segitiga," J. Pembelajaran Mat. Inov., vol. 4, no. 2, hal. 272-286, 2021, doi: 10.22460/jpmi.v4i2.277-286.
[9] N. Rokhima dan H. Fitriyani, "Student'S Metacognition: Do Intrapersonal Intelligent Make Any Difference?," Mosharafa J. Pendidik. Mat., vol. 7, no. 2, hal. 167-178, 2018, doi: 10.31980/mosharafa.v7i2.36.

[10] A. Kuzle, "Patterns of metacognitive behavior during mathematics problem-solving in a dynamic geometry environment," Int. Electron. J. Math. Educ., vol. 8, no. 1, hal. 2040, 2013.

[11] D. Purnomo, T. Nusantara, S. Subanji, dan S. Rahardjo, "The Characteristic of the Process of Students' Metacognition in Solving Calculus Problems," Int. Educ. Stud., vol. 10, no. 5, hal. 13, 2017, doi: 10.5539/ies.v10n5p13.

[12] H. Nindiasari, "Pengembangan Bahan Ajar Dan Instrumen Untuk Meningkatkan Berpikir Reflektif Matematis Berbasis Pendekatan Metakognitif Pada Siswa Sekolah Menengah Atas (SMA)," Pros. Semin. Nas. Mat. dan Pendidik. Mat. FMIFA Univ. Negeri Yogyakarta., hal. 251-263, 2011.

[13] A. Wisnanti, Sunardi, dan D. Trapsilasiwi, "Pengembangan Insrumen Penilaian Metakognisi Siswa Sekolah Menengah Pertama dalam Menyelesaikan Soal Cerita Matematika pada Pokok Bahasan Teorema Pythagoras Kelas VIII," vol. 5, 2014.

[14] M. Asy'ari, Muhamad Ikhsan, dan Muhali, "Jurnal Pengkajian Ilmu dan Pembelajaran Matematika dan IPA IKIP Mataram," vol. 6, no. 1, hal. 18-26, 2018.

[15] M. Zayyadi, S. I. Hasanah, dan A. Muhaimin, "Pengembangan Lembar Kegiatan Siswa dalam Pemecahan Masalah Matematika Dengan Pendekatan Metakognitif," Briliant J. Ris. dan Konseptual, vol. 3, no. 4, hal. 414, 2018, doi: 10.28926/briliant.v3i4.227.

[16] M. T. Magiera dan J. S. Zawojewski, "Characterizations of social-based and selfbased contexts associated with students'awareness, evaluation, and regulation of their thinking during small-group mathematical modeling," J. Res. Math. Educ., vol. 42, no. 5, hal. 486-520, 2011, doi: 10.5951/jresematheduc.42.5.0486.

[17] D. U. Setyaningrum dan H. L. Mampouw, "Proses Metakognisi Siswa SMP dalam Pemecahan Masalah Perbandingan Senilai dan Berbalik Nilai Mosharafa: Jurnal Pendidikan Matematika Mosharafa: Jurnal Pendidikan Matematika," Mosharafa J. 
Pendidik. Mat., vol. 9, no. 2, hal. 275-286, 2020, [Daring]. Tersedia pada: https://journal.institutpendidikan.ac.id/index. php/mosharafa/article/view/mv9n2_09/590.

[18] Budiyono, Pengantar Metodologi Penelitian Pendidikan. Surakarta: UNS Press, 2017.

[19] D. S. Setiana, "Pengembangan Instrumen Tes Matematika Untuk Mengukur Kemampuan Berpikir Kritis," J. Pendidik. Surya Edukasi, vol. 4, no. 2, hal. 35-48, 2018.

[20] S. Rahmatin, Rosary \& Khabibah, "Pengembangan Media Permainan Kartu Umath (Uno Mathematics) Dalam Pembelajaran Matematika Pada Materi Pokok Operasi Bilangan Bulat," MATHEdunesa, vol. 5, no. 1, 2016, [Daring]. Tersedia pada: https://jurnalmahasiswa.unesa.ac.id/index.ph p/mathedunesa/article/view/16667.

[21] S. Arikunto, Dasar-Dasar Evaluasi Pendidikan. Jakarta: Bumi Aksara, 2013.

[22] I. Ernawati, "Uji Kelayakan Media Pembelajaran Interaktif Pada Mata Pelajaran Administrasi Server," Elinvo (Electronics, Informatics, Vocat. Educ., vol. 2, no. 2, hal. 204-210, 2017, doi: 10.21831/elinvo.v2i2.17315.

[23] F. M. Sholekhah, N. Maharta, dan W. Suana, "Development of Higher Thinking Instrument of Newton 'S Laws of Motion," J. Phys. Sci. Learn., vol. 02, no. 1, hal. 17-26, 2018.

[24] S. R. Hidayat et al., "Pengembangan Instrumen Tes Keterampilan Pemecahan Masalah pada Materi Getaran, Gelombang, dan Bunyi," J. Penelit. Pengemb. Pendidik. Fis., vol. 3, no. 2, hal. 157-166, 2017, doi: $10.21009 / 1.03206$

[25] S. Ndiung dan M. Jediut, "Pengembangan instrumen tes hasil belajar matematika peserta didik sekolah dasar berorientasi pada berpikir tingkat tinggi," Prem. Educ. J. Pendidik. Dasar dan Pembelajaran, vol. 10, no. 1, hal. 94, 2020, doi: 10.25273/pe.v10i1.6274.

[26] A. Wardani, M. N. Arkan, dan A. Suyudi, "Pengembangan Instrumen Tes Keterampilan Pemecahan Masalah Pokok Bahasan Listrik Dinamis," J. Kependidikan Betara, vol. 1, no. 1, hal. 14-19, 2020.

[27] B. R. Kurniawan, M. Reyza, dan A. Taqwa, "Pengembangan Instrumen Tes Kemampuan Pemecahan Masalah Fisika pada Materi Listrik Dinamis," J. Pendidik. Teor. Penelitian, dan Pengemb., vol. 3, no. 11, hal.
1451-1457, 2018.

[28] R. S. Putri, Susanto, dan D. Kurniati, “Analisis Keterampilan Metakognitif Siswa dalam Menyelesaikan Masalah Matematika Berbasis Polya Subpokok Bahasan Garis dan Sudut Kelas VII-C di SMP Negeri 1 Genteng Banyuwangi ( The Analysis of Student' $\mathrm{s}$ Metacognition Skills in Resolving Mathematics Prob," Artik. Ilm. Mhs., vol. II, no. 1, hal. 1-7, 2015.

[29] S. Mubarak, E. Susilaningsih, dan E. Cahyono, "Pengembangan Tes Diagnostik Three Tier Multiple Choice untuk Mengidentifikasi Miskonsepsi Peserta Didik Kelas XI," J. Innov. Sci. Educ., vol. 5, no. 2, hal. 101-110, 2016. 